\title{
EDUKASI PERUBAHAN PRILAKU DALAM PENCEGAHAN PENYEBARAN COVID-19
}

\author{
Education Of Changes In Prevention Of The Spread Of Covid-19
}

\begin{abstract}
ABSTRAK
Program edukasi perubahan perilaku adalah program yang bertujuan untuk meningkatkan jumlah individu, keluarga, institusi dan komunitas yang patuh protokol kesehatan terutama 3M Kita harus melibatkan partisipasi seluruh lapisan masyarakat, tanpa terkecuali, untuk melakukan perubahan perilaku agar bisa memenangkan peperangan ini. Perubahan perilaku yang sering dikenal dengan istilah 3M (memakai masker, menjaga jarak dan menghindari kerumunan, serta mencuci tangan pakai sabun). Metode pada pelaksanaan kegiatan edukasi perubahan prilaku dilakukan secara luring yang dilaksanakan selama 10 (sepuluh) hari. Kegiatan ini diikuti 2 orang mahasiswa dan 1 orang DPL (Dosen Pembimbing Lapangan) yang dilaksanakan pada bulan Oktober 2020 disekitar Jatiasih, Kota, bekasi. Kegiatan edukasi yang dilaksanakan selama sepuluh hari didapatkan bahwa masyarakat telah mematuhui protocol kesehatan Penerapan 3M dapat dilakukan dengan menjalankan setidaknya 3 (tiga) perilaku disiplin yaitu: Memakai masker Mencuci tangan Menjaga jarak dan menghindari kerumunan.
\end{abstract}

Kata Kunci : edukasi, perubahan, perilaku, 3M

\section{ABSTRACT}

Behavior change education programs are programs that aim to increase the number of individuals, families, institutions and communities that comply with health protocols, especially $3 M$. We must involve the participation of all levels of society, without exception, to make behavior changes in order to win this war. Changes in behavior that are often known as 3M (wearing masks, keeping your distance and avoiding crowds, and washing your hands with soap). The method in implementing behavior change education activities is carried out offline which is carried out for 10 (ten) days. This activity was attended by 2 students and 1 DPL (Field Supervisory Lecturer) which was held in October 2020 around Jatiasih, Kota, Bekasi. Educational activities carried out for ten days found that the community has complied with the health protocol. The implementation of $3 \mathrm{M}$ can be done by carrying out at least 3 (three) disciplinary behaviors, namely: Wearing a mask Washing hands Keeping distance and avoiding crowds.

Keywords : education, change, behavior, $3 M$

\section{PENDAHULUAN}

Corona virus 2019 atau Corona Virus Disease-19 (COVID-19) merupakan penyakit infeksi saluran pernapasan yang disebabkan oleh jenis virus corona. Kasus COVID-19 pertama kali dilaporkan di Kota Wuhan, Provinsi Hubei, Tiongkok, pada bulan Desember 2019. Dalam beberapa bulan, penyebaran penyakit tersebut telah menyebar ke berbagai negara, baik di Asia, Amerika, Eropa, dan Timur Tengah serta Afrika. Pada tanggal 11 Maret 2020, Organisasi Kesehatan Dunia atau World Health Organization (WHO) mendeklarasikan penyebaran COVID-19 dikategorikan sebagai pandemic. ${ }^{1}$

$$
\text { Covid-19 merupakan salah satu }
$$

penyebab penyakit menular yang perlu diwaspadai. Virus corona ini menjadi patogen penyebab utama outbreak penyakit pernapasan. Virus ini adalah virus RNA rantai tunggal (single-stranded RNA) yang dapat diisolasi dari beberapa jenis hewan, terakhir disinyalir virus ini berasal dari kelelawar kemudian berpindah ke manusia.. Pada tanggal 11 Maret 2020 WHO mengumumkan bahwa COVID-19 menjadi pandemi di dunia. Sejak diumumkan pertama kali ada di Indonesia, kasus COVID19 meningkat jumlahnya dari waktu ke waktu sehingga memerlukan perhatian. ${ }^{1}$

Musuh yang kita hadapi bersama saat ini adalah Covid-19. penyebarannya cepa. Penyakit ini dapat membawa akibat buruk, sampai ke kematian. Kecepatan penyebaran virus Covid-19 harus segera dihambat dan 
langkah terbaik yang harus kita lakukan adalah fokus untuk memutus mata rantai penularannya dengan menempatkan perubahan perilaku sebagai ujung tombak pengendalian Covid-19.

Kita harus melibatkan partisipasi seluruh lapisan masyarakat, tanpa terkecuali, untuk melakukan perubahan perilaku agar bisa memenangkan peperangan ini. Perubahan perilaku yang sering dikenal dengan istilah $3 \mathrm{M}$ (memakai masker, menjaga jarak dan menghindari kerumunan, serta mencuci tangan pakai sabun). Perilaku merupakan aksi atau tindakan seseorang terkait diri sendiri maupun orang lain.

Perilaku merupakan reaksi manusia akibat kegiaan kognitif, afektif, dan psikomotorik. Ketiga aspek tersebut saling berhubungan. Aapabila salah satu aspek mengalami hambatan, maka aspek perilaku lainnya juga akan mengalami gangguan ${ }^{2}$

Kesehatan adalah keadaan sehat baik fisik, mental, spiritual maupun sosial yang akan memungkinkan setiap orang hidup produktif secara sosial ekonomis. Pemerintah dan masyarakat bertanggungjawab melakukan upaya pencegahan, pengendalian, dan pemberantasan penyakit serta akibat yang ditimbulkan. Hal ini perlu dilakukan, karena kesehatan bukanlah tanggungjawab pemerintah saja, namun merupakan tanggungjawab bersama, pemerintah, dan masyarakat.

Teori Blum menyebutkan bahwa social behaviour merupakan perilaku anggota masyarakat terhadap sesamanya, keluarga, komunitas dan bangsanya. Interpersonal relationship, yaitu kualitas komunikasi anggota masyarakat terhadap sesamanya. ${ }^{3}$

Tujuan pogram edukasi perubahan perilaku adalah untuk meningkatkan jumlah individu, keluarga, institusi dan komunitas yang patuh protokol kesehatan terutama $3 \mathrm{M}$. Sasaran edukasi mahasiswa perubahan perilaku adalah masyarakat dengan kelompok rentan: usia > 45 tahun, orang dengan penyakit penyerta, ibu hamil, anak 0-8 tahun, penyandang disabilitas, kelompok yang tinggal bersama anggota keluarga positif COVID-19, dan kelompok rentan dengan kondisi ekonomi keluarga kurang mampu. Individu: Kolega mahasiswa, Guru dan dosen, peserta didik, dan keluarga peserta didik di lingkungan sekitar.
Komunitas Kewilayahan: lingkungan RT, RW, kelurahan/desa. ${ }^{4}$

\section{METODE}

Metode pada pelaksanaan kegiatan edukasi perubahan prilaku dilakukan secara luring yang dilaksanakan selama 10 (sepuluh) hari. Kegiatan ini diikuti 2 orang mahasiswa dan 1 orang DPL (Dosen Pembimbing Lapangan) yang dilaksanakan pada bulan Oktober 2020 disekitar Jatiasih, Kota, bekasi.

\section{HASIL DAN PEMBAHASAN}

\section{HASIL}

sebelum melakukan kegiatan mahasiswa melakukan pemantauan disekitar Jatiasih, Kota, bekasi dengan hasil sebagai berikut:

\begin{tabular}{|c|c|c|c|c|}
\hline No & $\begin{array}{l}\text { Hari ke- } \\
\text { /Lokasi }\end{array}$ & Temuan & Kegiatan & Evaluasi \\
\hline 1. & $\begin{array}{l}\text { 1/ Jl. } \\
\text { Asabri, } \\
\text { RT.003/R } \\
\text { W.011, } \\
\text { Jatiluhur, } \\
\text { Kec. } \\
\text { Jatiasih, } \\
\text { Kota Bks, } \\
\text { Jawa Barat }\end{array}$ & $\begin{array}{l}\text { Terdapat } \\
\text { kerumunan } \\
\text { warga di } \\
\text { warung } \\
\text { sayur }\end{array}$ & $\begin{array}{l}\text { Edukasi } 3 \\
\text { M }\end{array}$ & $\begin{array}{l}\text { beberapa } \\
\text { warga sudah } \\
\text { melakukan } \\
\text { jaga jarak } \\
\text { namun masih } \\
\text { abai akan } \\
\text { pemakaian } \\
\text { masker }\end{array}$ \\
\hline 2. & $\begin{array}{l}\text { 2/ Jalan } \\
\text { Wibawa } \\
\text { Mukti II } \\
\text { KM V, } \\
\text { RT.004/R } \\
\text { W.004, } \\
\text { Jatisari, } \\
\text { Kec. } \\
\text { Jatiasih, } \\
\text { Kota } \\
\text { Bks, Jawa } \\
\text { Barat }\end{array}$ & $\begin{array}{l}\text { Warga } \\
\text { tidak } \\
\text { memakai } \\
\text { masker dan } \\
\text { menjaga } \\
\text { jarak }\end{array}$ & $\begin{array}{l}\text { Edukasi } 3 \\
\text { M }\end{array}$ & $\begin{array}{l}\text { warga sudah } \\
\text { melakukan } \\
\text { jaga jarak }\end{array}$ \\
\hline 3. & $\begin{array}{l}\text { 3/ Jalan } \\
\text { Surya } \\
\text { Darma } \\
\text { Jatisari, } \\
\text { Kec. } \\
\text { Jatiasih, } \\
\text { Kota } \\
\text { Bks, Jawa } \\
\text { Barat }\end{array}$ & $\begin{array}{l}\text { Terdapat } \\
\text { kerumunan } \\
\text { warga } \\
\text { lebih dari } 5 \\
\text { orang }\end{array}$ & $\begin{array}{l}\text { Edukasi } 3 \\
\text { M }\end{array}$ & $\begin{array}{l}\text { Beberapa } \\
\text { warga sudah } \\
\text { dihimbau } \\
\text { untuk } \\
\text { menggunakan } \\
\text { masker } \\
\text { terutama } \\
\text { pedagang } \\
\text { yang } \\
\text { berkontak } \\
\text { langsung } \\
\text { dengan } \\
\text { pangan. }\end{array}$ \\
\hline
\end{tabular}




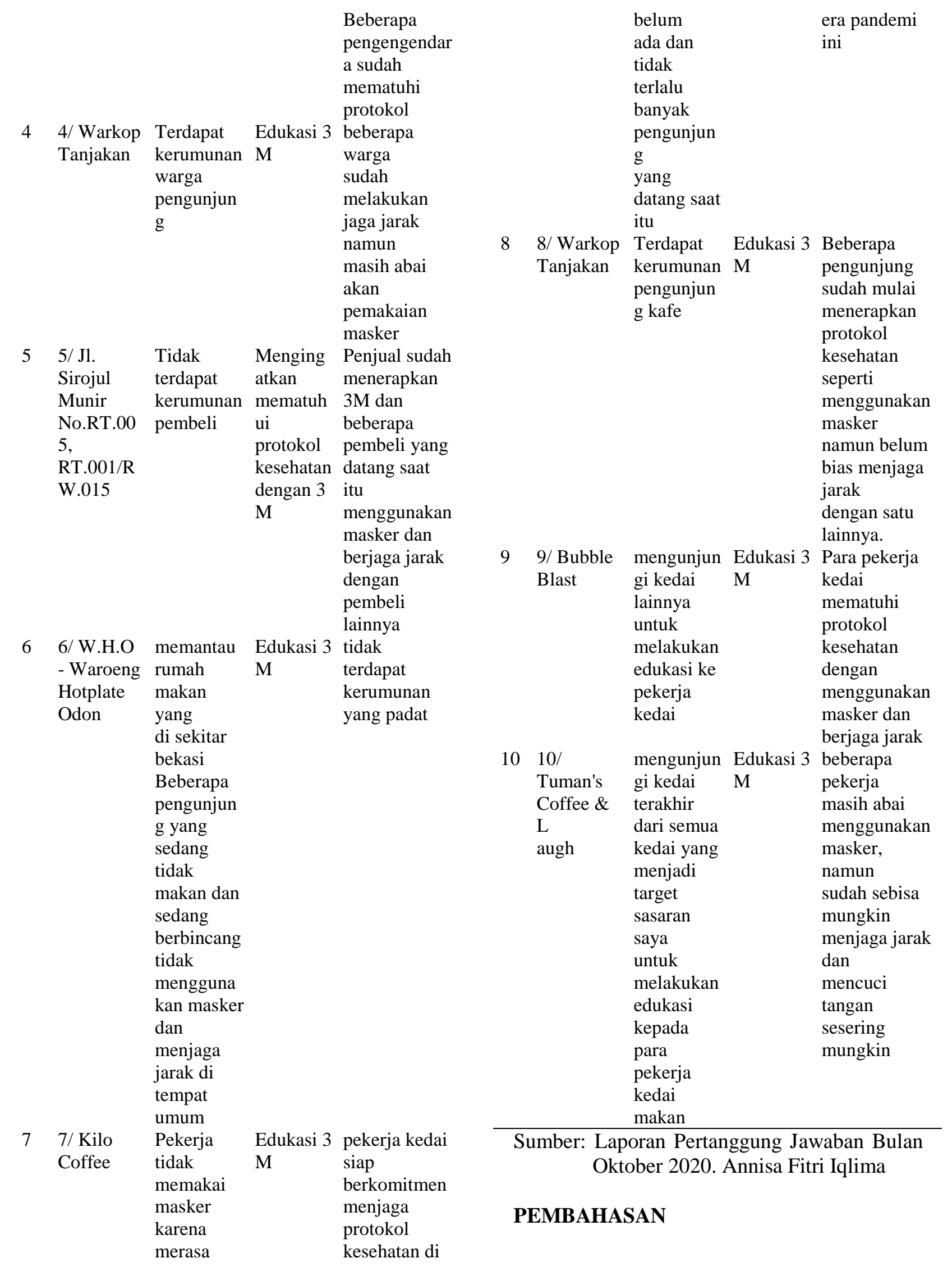


Musuh yang kita hadapi bersama saat ini adalah Covid-19. penyebarannya cepa. Penyakit ini dapat membawa akibat buruk, sampai ke kematian. Kecepatan penyebaran virus Covid-19 harus segera dihambat dan langkah terbaik yang harus kita lakukan adalah fokus untuk memutus mata rantai penularannya dengan menempatkan perubahan perilaku sebagai ujung tombak pengendalian Covid-19.

Kita harus melibatkan partisipasi seluruh lapisan masyarakat, tanpa terkecuali, untuk melakukan perubahan perilaku agar bisa memenangkan peperangan ini. Perubahan perilaku yang sering dikenal dengan istilah $3 \mathrm{M}$ (memakai masker, menjaga jarak dan menghindari kerumunan, serta mencuci tangan pakai sabun). Perilaku merupakan aksi atau tindakan seseorang terkait diri sendiri maupun orang lain.

Tujuan pogram edukasi perubahan perilaku adalah untuk meningkatkan jumlah individu, keluarga, institusi dan komunitas yang patuh protokol kesehatan terutama $3 \mathrm{M}$. Sasaran edukasi mahasiswa perubahan perilaku adalah masyarakat dengan kelompok rentan: usia > 45 tahun, orang dengan penyakit penyerta, ibu hamil, anak 0-8 tahun, penyandang disabilitas, kelompok yang tinggal bersama anggota keluarga positif COVID-19, dan kelompok rentan dengan kondisi ekonomi keluarga kurang mampu. Individu: Kolega mahasiswa, Guru dan dosen, peserta didik, dan keluarga peserta didik di lingkungan sekitar. Komunitas Kewilayahan: lingkungan RT, RW, kelurahan $/$ desa $^{4}$

Penyebaran virus Corona atau COVID-19 di Indonesia harus ditekan semaksimal mungkin. Salah satu cara utamanya adalah dengan menerapkan perilaku hidup disiplin.
Maka, selalu \#ingatpesanibu dengan melakukan langkah 3M sebagai upaya mencegah sekaligus memutus rantai penularan COVID-19.

Membiasakan dan mewajibkan diri untuk mematuhi protokol kesehatan merupakan salah satu kunci agar virus COVID-19 dapat ditekan penyebarannya. Namun, dibutuhkan perilaku disiplin dari dari sendiri, juga sangat perlu untuk dilakukan secara kolektif dengan penuh kesadaran.

Kegiatan edukasi yang dilaksanakan selama sepuluh hari didapatkan bahwa masyarakat telah mematuhui protocol kesehatan Penerapan 3M dapat dilakukan dengan menjalankan setidaknya 3 (tiga) perilaku disiplin yaitu: Memakai masker Mencuci tangan Menjaga jarak dan menghindari kerumunan.

\section{KESIMPULAN}

Kegiatan edukasi yang dilaksanakan selama sepuluh hari didapatkan bahwa masyarakat telah mematuhui protocol kesehatan Penerapan 3M dapat dilakukan dengan menjalankan setidaknya 3 (tiga) perilaku disiplin yaitu: Memakai masker Mencuci tangan Menjaga jarak dan menghindari kerumunan

\section{DAFTAR PUSTAKA}

Pedoman tatalaksana Covid-19 edisi-2

Zan PH. 2010. Pengantar psikologi untuk kebidanan.Jakarta: Prenada Media Goup

Blum HL. 1974. Planning for health, development and aplication of social changes theory. New York: Human Sciences Press

Pedoman Edukasi PP 